\title{
LOGISTICS SUPPORT PLANNING MODEL IN THE CONDITIONS OF LIMITED RESOURCES
}

\author{
Nikola B. Simića , Marjan A. Milenkov ${ }^{b}$, \\ Vladimir R. Milovanovićc, Vlada S. Sokolovićd, \\ Pavel J. Foltine, Balázs J. Taksás ${ }^{\dagger}$ \\ a University of Defence in Belgrade, Military Academy, \\ Department for Logistics, Belgrade, Republic of Serbia, \\ e-mail: nikolasimicva@hotmail.com, \\ ORCID iD: (iohttps://orcid.org/0000-0002-0561-6555 \\ b University of Defence in Belgrade, Military Academy, \\ Department for Logistics, Belgrade, Republic of Serbia, \\ e-mail: marjan.milenkov@va.mod.gov.rs, \\ ORCID iD: —https://orcid.org/0000-0003-2054-0525 \\ c University of Defence in Belgrade, Military Academy, \\ Department for Logistics, Belgrade, Republic of Serbia, \\ e-mail: vaci84milovanovic@gmail.com, \\ ORCID iD: 10 https://orcid.org/0000-0002-6787-4058 \\ d University of Defence in Belgrade, Military Academy, \\ Department for Logistics, Belgrade, Republic of Serbia, \\ e-mail: vlada.sokolovic@va.mod.gov.rs, corresponding author, \\ ORCID iD: 『https://orcid.org/0000-0003-0782-0506 \\ e University of Defence in Brno, Faculty of Military Leadership, \\ Department of Logistics, Brno, Czech Republic, \\ e-mail: pavel.foltin@unob.cz, \\ ORCID iD: (Dhttps://orcid.org/0000-0001-8270-0390 \\ ${ }^{f}$ University of Public Service, Faculty of Military Science and Officer \\ Training, Department of Supply, Finance and Military Transportation, \\ Budapest, Hungary, \\ e-mail: taksas.balazs@uni-nke.hu, \\ ORCID iD: (Dhttps://orcid.org/0000-0001-7583-4198
}

DOI: 10.5937/vojtehg70-33079; https://doi.org/10.5937/vojtehg70-33079

FIELD: Logistics, Engineering management, Information technology ARTICLE TYPE: Original scientific paper

ACKNOWLEDGMENT: The work stemmed from the Model of Logistics Support Planning Support System (VA-TT-1 / 20-22) Project, Military Academy, University of Defense in Belgrade. 


\begin{abstract}
:
Introduction/purpose: The paper presents a model of logistics support planning in the conditions of limited logistic resources based on the prioritization of customer requirements and resource allocation. Decisionmakers play a crucial role in the efficient and equitable allocation of resources as they prioritize among different user requirements.
\end{abstract}

Methods: Requirement prioritization techniques that use nominal scale, ordinal scale, and ratio scale, and five methods for converting ranks into weighting coefficients have been applied to determine the degree of significance of user requirements. The Requirements triage method has been used for establishing relative priorities, while the heuristic algorithm determining the Kemeny median was used to consolidate individually ranked requests into a group rank. In order to balance opposing demands of users, consensus measures of group decision making were used. For obtaining an optimal planned solution of logistic support, the methods and techniques of resource allocation were applied.

Results: A model for adaptive planning of logistics support in the conditions of limited resource capacities of the logistics system has been developed.

Conclusion: The proposed model can be effectively applied in other areas of resource allocation.

Keywords: logistics planning, requirement prioritization, triage, converting ranks into weights, resource allocation.

\title{
Introduction
}

Logistics support planning is a highly complex problem in a military organization. Research shows that even the most powerful armies in the world face numerous issues in planning the logistic support of military operations (McConnell \& King, 2019). The most common problems faced by military logisticians are difficulties in forecasting, lengthy work, mismatch of requirements, and poor visibility of logistic resources.

It is generally known that many logistics aspects (user requirements, resource capacities, operational environment, time, etc.) are stochastic, dynamic, and nonlinear, which causes high sensitivity of the logistic system (Milenkov et al, 2020).

For military units to maintain the combat strength needed to conduct operations in the new environment, whether combat or humanitarian, research shows that armies will need to fundamentally improve their logistics models used in the previous period and conduct extensive logistics planning (Hurley \& Coleman, 2018). 
During the logistics support planning process, logistics bodies have an essential role, first to understand and then to balance opposing requirements of users, and with their knowledge, competence, and ability to create an optimal Logistics Support Plan which will, in the observed planning period, ensure the best overall military organization performance with a limited resource capacity of the logistic system (Jia et al, 2020).

All these limitations motivated the authors to explore the possibility of applying the allocation of limited resources to the existing logistics system and develop an awareness of the need to modernize the way of thinking, decision making, and reducing the stress of logistics organs due to increased outflow of staff.

Whenever deadlines are short, resources are limited and user requirements exceed the resource capacities of the logistic system, it implies that some requirements would not be completely met. In that case, it is necessary to decide which requirements will be fully completed, which partially, and which will not be completed, i.e. it is essential to prioritize the requirements and allocate resources with which the conflicting user requirements will be met to a certain extent. Accordingly, priority prioritization and resource allocation are significant activities in logistics support planning.

Determining the needs for ammunition (Zlatnik \& Mares, 2020), fuel, spare parts, food and water items, determining the occurrence of failure on assets, as well as the place and time of service procedures, requires extensive calculations and forecasts. To take specific measures to meet these needs, logistics authorities must gain direct insight into the state of availability of resource capacities of the logistics network (no matter whether it is material stocks or maintenance capacities). These problems cannot be adequately solved without modern decision support tools that can predict rapid changes in logistic requirements and analyze the resource capacities of the logistic network (McConnell et al, 2021). Some of these tools, which can be found in the literature, belong to MCDM methods: MARCOS, CODAS, EDAS, VIKOR, MABAC, and many others (Li et al, 2020).

MARCOS (Measurement of Alternatives and Ranking according to COmpromise Solution) considers an anti-ideal and ideal solution at the very beginning of the formation of an initial matrix, closer determination of utility degree concerning solutions, a proposal of a new way to determine utility functions, a possibility to consider a large set of criteria and alternatives while maintaining the stability of the method (Sarma et al, 2020). 
CODAS stands for COmbinative Distance-based Assessment, and it is used to determine the desirability of an alternative. This method uses the Euclidean distance as the primary and the Taxicab (non-Euclidean) distance as the secondary measure, and these distances are calculated according to the negative-ideal point. The alternative which has greater distances is more desirable in the CODAS method.

The desirability of alternatives in the Evaluation Based on Distance from Average Solution (EDAS) method is determined based on their distances from an average solution. Because the average solution is determined by the arithmetic mean in this method, the EDAS method can be efficient for solving stochastic problems.

VIKOR (Multicriteria Optimization and Compromise Solution in Serbian) solves decision problems with conflicting and noncommensurable (different units) criteria. Assuming that compromise is acceptable for conflict resolution, the decision-maker wants a solution that is closest to the ideal one, and the alternatives are evaluated according to all established criteria. It ranks alternatives and determines the solution named compromise that is closest to the ideal.

The MABAC (multi-attributive border approximation area comparison) model handles the complex and uncertain decision-making issues by computing the distance between each alternative and the bored approximation area (Pamučar \& Savin, 2020).

Based on all the above, the goal of this paper primarily indicates the growing need to develop the logistics planning process, and the final transition from traditional thinking to more modern, innovative solutions to keep pace with foreign armies. In practice, this would be reflected in a fast decision-making process using information systems based on modern resource allocation models to reduced logistics staff effort and shorten response time.

The current process of manual logistic support planning requires a high level of resourcefulness, combinatorics, and calculations to perform all the defined tasks with the best possible results. Based on practical experience, the method of allocation of limited resources was applied in this paper as a starting point for the development of a simplified logistics support plan. Certainly, this paper should contribute to the development of logistics support and the planning process in the army in general, given that the existing literature does not recognize this way of solving the allocation of resources (Daoud et al, 2021).

Nowadays, research shows that even in modern armies, logistics planners do not have adequate tools to help them provide quick answers to questions, especially in a time-limited expedition planning environment (Schwartz et al, 2019). Therefore, the development of more intelligent 
planning and analytics tools is enabling the military to expand logistics innovations further and improve the efficiency of the logistics system.

\section{Basic features of the logistics support planning}

The logistics support planning is a complex undertaking that requires good forecasting, logistics network optimization, and risk analysis in a highly uncertain environment (Rogers et al, 2018).

The goal of the logistics support planning is to determine the optimal logistics resources, as well as the order, manner, and deadlines for performing logistics support tasks and elaboration of measures, based on the elaborated variant of using engaged forces, objective assessment of the situation, and accurate calculations and activities to increase the efficiency of the logistics system, its stability, and vitality.

Logistics support planning is a segment of the operational planning process and represents a very dynamic process with a defined goal that takes place at a specific time. It requires a creative and organized action of the logistics management bodies which is a necessary condition for achieving a certain degree of organization in preparing executive logistic staff and their precise work plan. The action should be harmonized concerning the set goal, time, and space for the execution of tasks.

In the last period, the countenance of modern military operations has changed radically, which has led to a change in the operational environment and the use of military forces. Modern operations are primarily reflected in the increasingly stringent and complex requirements of users in terms of speed, safety, quality, quantity, and diversity of providing the necessary resources. The emerging operational environment is changing rapidly and requires rapid responses, which has led to traditional military planning not offering good enough solutions.

New approaches to military planning should be able to deal with emerging issues by providing solutions that are robust to deviations from ordinary circumstances and be easily adaptable to new information that becomes known during the execution of the plan, thus increasing effectiveness and efficiency in military operations (Zeimpekis et al, 2015).

Traditional planning seeks solutions that require minimal modifications of the plan during the execution phase. Such an approach to initial plan development may require relatively large calculations. On the other hand, agile planning requires quick solutions that allow a plan modification and re-planning to anticipate events and information during the execution phase (Zeimpekis et al, 2015). 
The basic elements considered in logistics support planning for a military operation, as complex actions of the project type, are user requirements viewed as activities to be serviced, time, resources, and costs.

Resources are usually of limited capacity, which leads to the fact that user requests for a specific type of resource are more significant than the ability of the logistics system to fully meet all requests in one particular (given, planned) period of time. In that case, the process of planning the allocation of limited resources is very complex because the logistics authorities are faced with the problem of how to provide an effective, efficient and fair way to meet user requirements while obtaining the most significant global utility of the military system.

Implementing an effective policy of planning and resource management in military logistics requires constant monitoring and a comprehensive analysis of the availability of actual and potential logistic resources. This enables the development of an optimal system of resource allocation among interested users, taking into account the introduction of modern technologies and energy savings (Kostiuchenko \& Solomon, 2020).

The approaches to solve the problem of the rational allocation of limited logistic resources, in the logistics planning process, depending on the policy of resource adjustment, can be classified as follows:

- To firmly set a deadline, with a known scope and type of requirements and engage resources sufficient to all user requirements to be met. In this case, a cost minimization strategy is applied;

- To find a solution for known available (limited) resources, with a known scope and type of requirements, which will provide a minimum extension of time to provide the necessary resources and meet all user requirements. In this case, a time minimization strategy is applied;

- To select the type and scope of requirements that can be met, to achieve maximum effects, for known available (limited) resources, in a firmly set period of time. In this case, the strategy of maximizing the global utility is applied, i.e. the rule of allocative or Pareto efficiency.

In the process of the logistics support planning, logistics staff should continuously observe, study and analyze user requirements in different ways and from different points of view, and generally have to make many decisions based on individual perception and experimentally chosen criteria, to respond to the requirements as rationally as possible to users 
with available resource capacities of the logistics system (Milenkov et al, 2020).

Figure 1 presents a logistics support planning model.

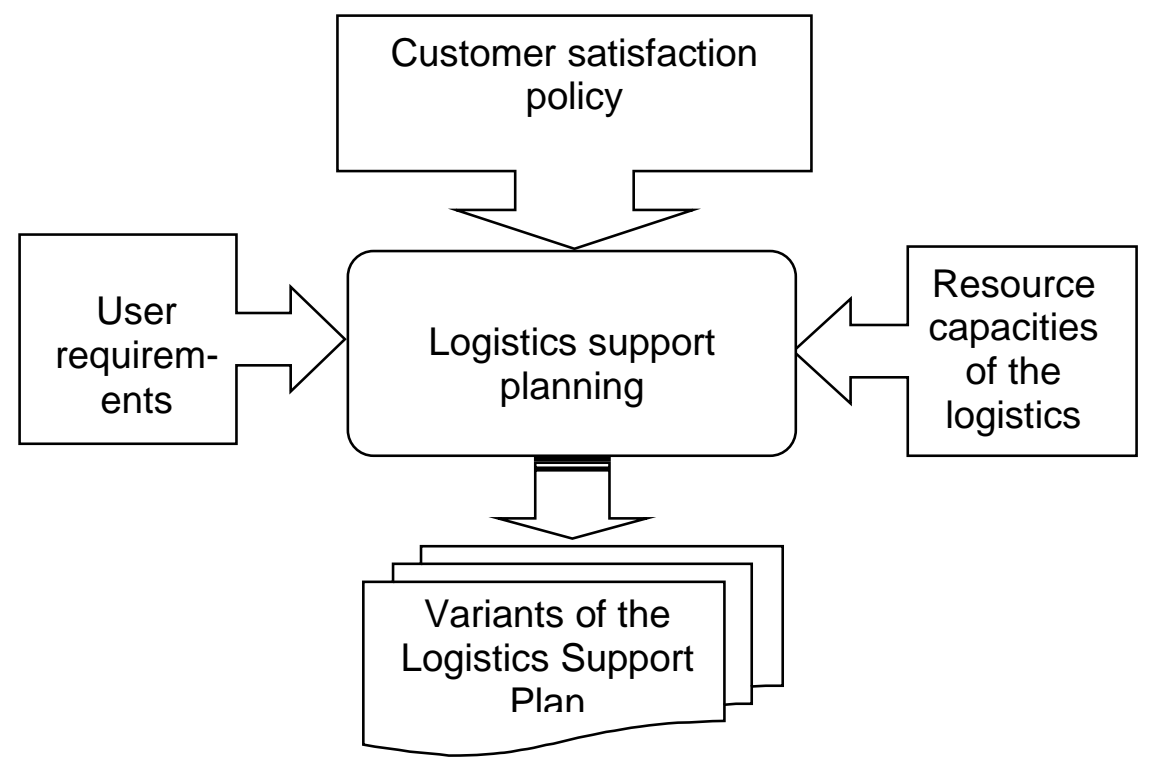

Figure 1 - Logistics support planning model

Puc. 1 - Модель планирования логистической поддержки

Слика 1 - Модел планирања логистичке подршке

The result of the planning process is the Logistics Support Plan, a document in which the planning actions are written towards the set goal. The development of the plan concretizes the goal and determines in more detail what needs to be done to reach the goal, having in mind the probable development of future events. The concretization of the goal includes answers to the questions: what needs to be done, who needs to do it, when it needs to be done, where it needs to be done, with what to do it (with what resources), and how to do it. It aso needs back-up solutions in the case the assumptions and limitations on which the plan change is based (Andrejić et al, 2004; Andrejić, 2001).

The plan must be flexible enough to allow for changes and additions, thus expressing the continuity of the planning process. So, continuity of planning requires reviewing the goals and, if necessary, redefining them, i.e. revising the plan in certain time intervals. In general, the logistics support planning process includes the following steps:

- Determining customer requirements, expressed through the 
necessary resource capacities of the logistics system;

- Determining the available resource capacities of the logistics system in the observed planning period;

- Determining the deviation of the required and available resource capacity;

- Choice of policy to meet customer requirements;

- Development of alternative planning solutions;

- Selection of a planning solution from the set of acceptable solutions; and

- Concretization (detailed elaboration) of the selected planning solution.

These activities indicate that in the process of logistics support planning, it is necessary to apply adequate models for the allocation of limited logistic resources in accordance with the conflicting requirements of the users to achieve better global utility of military formation.

It is obvious that solving the problem of allocating limited resources during the logistics support planning process requires the involvement of several stakeholders, which in organizational terms is a collective (group) way of decisions making. Therefore, it is imperative to adhere to certain principles, adopted priorities and present restrictions to mitigate the conflict of the user requirements and make the Logistics Support Plan as efficient as possible.

\section{Logistics support planning based on prioritization of requests and allocation of limited resources}

In the broader context of logistics support planning, the first important question that arises is what to allocate and to whom to allocate it, while the second question is how much to allocate. The answers to these questions are very complex and must be assessed against the higher goals of the military organization, especially when there are limited resource capacities of the logistics system. In this regard, the problem of resource allocation is an essential and challenging task in logistics support planning, where logistics resource capacities such as material resources, intangible items (e.g. services), and human resources are allocated in accordance with user requirements.

In general, the problem of resource allocation is present in various fields and attracts the attention of many researchers and practitioners. Different approaches to resource allocation are presented in the literature, which is based on specialized mathematical models and 
algorithms (Luss, 2012). These models are used in many areas, such as industrial production management, communication, and computer networks, emergency services, health services, air traffic, allocation of water rights, environmental and military issues (Luss, 2012; Meran et al, 2021; Skobelev, 2011; Hameed et al, 2016).

The central question in resource allocation problems is how to optimize a goal based on certain criteria. In such problems, there are often contradictions and tensions in establishing a certain balance between user requirements because achieving one value can be detrimental to another. These problems are often modelled so that the immediate outcome of optimization is a Pareto set of sustainable solutions (Chevaleyre et al, 2006; Ogryczak et al, 2014).

If there are conflicting goals among interested users, the Pareto set contains several solutions that represent different trade-offs in conflicts over resources. The basic goal of solving such problems is to choose the best compromise for a particular domain in which optimization is applied (Luss, 1999).

Resource allocation is a problem of discrete optimization and belongs to the category of NP-heavy (non-deterministic polynomial-time hardness) problems. Finding solutions that meet all the limitations means searching for a vast space of possible solutions. Therefore, the application of advanced techniques that use different heuristics to narrow the search space allows us to find a solution that is close to optimal.

The development of fully automated systems for solving allocation problems is often rejected in practice. The reason may be restrictions that are difficult to register fully, decision criteria difficult to determine, and end-users not usually being experts in using complex mathematical concepts such as large matrices of mathematical programming or weighting factors of multicriteria optimization.

In the conditions of uncertainty, logistics staff in charge of logistics support planning often have incomplete, inaccurate, contradictory, insufficiently clear, and insufficiently reliable information on user requirements and available resource capacities of the logistics system, which complicates the process of determining the distribution of resources in the logistics system in accordance with customer requirements.

In the case when resource capacities of the logistic system are insufficient to meet all user requirements, specific heuristic rules can provide great assistance to logistics authorities in choosing a policy to meet user requirements, such as:

- Rule "First come, first served"; 
- Rule "The most urgent request is served first";

- Rule "The request whose realization lasts the shortest is served first";

- Rule "The nearest date is executed first" (request with the shortest time - waiting period);

- Rule "Priority of requests, i.e. ranking of requests according to the degree of significance".

Prioritization of requirements has proven in practice as an effective strategy in the allocation (distribution) of resources that facilitates the decision-making process and allows suppliers to efficiently and fairly provide resources to a larger number of users (Luss, 2012).

\section{Limited resource allocation model}

To solve the problem of the logistics support planning, it is necessary to know the requirements of users $(i=1,2, \ldots, m)$ for a particular type of resource $\left(B_{i j}\right)$, and, on the other hand, it is necessary to know the availability of required resource capacities of the logistic system $\left(R_{j}\right)$ for the observed planning period.

The value $\left(B_{i j}\right)$ represents the needs of the $i$-th user $(i=1,2, \ldots, m)$ for the $j$-th type of resource $(j=1,2, \ldots, n)$, i.e. $B_{j}=\sum_{i=1}^{m} B_{i j}$ it represents the total required amount of the $j$-th type of resource of all $m$ users. At the same time, the size $\left(R_{j}\right)$ represents the availability of the $j$-th type of resources in the observed planning period.

Satisfaction of specific user requirements with the $j$-th type of available resources $\left(R_{j}\right)$ can be presented as follows:

$$
R_{j}=\sum_{i=1}^{k} R_{i j}^{+}+\sum_{i=k+1}^{l} R_{i j}^{*}+\sum_{i=l+1}^{m} R_{i j}^{-}
$$

where:

$R_{j}^{+}$- the amount of the $j$-th type of resource with which it entirely (100\%) meets specific user requirements $(i=1, \ldots, k)$, $R_{j}^{*}$ - the amount of the $j$-th type of resource with which specific $i$-th user requirements are partially met $(i=k+1, \ldots, l)$, 
$R_{j}^{-}$- the missing amount of the $j$-th type of resource due to which the $i$-th user requirements are determined $(i=l+1, \ldots, m)$ unsatisfactory.

Depending of resources availability, two basic planning categories can be applied: resource levelling and resource allocation.

The problem of levelling resources arises in the case when there is a sufficient amount of available resources of the logistic system to meet all user requirements in the observed planning period entirely. Here, it is essential to fulfill the condition of timeliness of satisfying all user requests, which is achieved by determining the order of satisfying user requests for a specific type of resource.

In this case, the needs of all users are fully met, and the solution to the problem of resource planning is unambiguous and comes down to the distribution of the size of available resources $\left(R_{j}\right)$ of a series of quantities $\left(B_{i j}\right)$, where the condition is satisfied:

$$
B_{j}=\sum_{i=1}^{m} B_{i j} \leq R_{j}
$$

The size $R_{j}$ represents the available amount of resources, i.e. $R_{j}=R_{j}^{\prime}+r_{j}$, where the size $R_{j}^{\prime}$ represents the number of resources that are allocated to user requirements, while $r_{j}$ represents the number of resources that remain after distribution, i.e. represents the excess resources for the observed planning period.

The problem of resource allocation occurs when resources are limited, i.e. insufficient to meet all user needs in the observed planning period, which can be mathematically represented with the following expression:

$$
B_{j}=\sum_{i=1}^{m} B_{i j}>R_{j}
$$

In this case, there is a shortage of resources, which for the $j$-th type of resource is:

$$
\Delta R_{j}=B_{j}-R_{j}
$$

The size $\Delta R_{j}$ should be taken away from the users in some way to cover the existing lack of required resources. 
The solution to this problem comes down to allocating the available amount of the resources $R_{j}^{*}$ to the order of new quantities $b_{i j}^{*}$ to satisfy the following condition:

$$
R_{j}^{*}=\sum_{i=1}^{m} b_{i j}^{*}, \text { respectively } R_{j}^{*}=\sum_{i=1}^{m} B_{i j}-\Delta R_{j}
$$

This can be done by shortening the required amount of resources to each user by the number of missing resources $\delta_{i j}$, so that $\Delta R_{j}$ represents the total amount of missing resources that could cover the resulting shortage or meet the condition:

$$
\Delta R_{j}=\sum_{i=1}^{m} \delta_{i j}
$$

where: $\delta_{i j}$ - reduced amount of the $j$-th resource to the $i$-th user.

Research on resource allocation problems shows that ranking user requests according to the degree of importance, seeking or sharing the same resource, is an important activity when deadlines are short and resources are limited (Lehtola et al, 2004). Requirements prioritization is the setting of ranks or ratings of importance to a set of requirements based on specific criteria and according to the viewpoints of various stakeholders (Moisiadis, 2002, Ogryczak et al, 2014).

In addition, when ranking the requests, what is important is the method of determining the coefficient of the significance of the request concerning the obtained rank.

From the set conditions and specific priority requests of the user $\left(K_{i j}\right)$ for a specific type of resource, the coefficient of the significance of the request of the $i$-th user for the $j$-th type of resource can be determined $\left(\mu_{i j} \in[0,1]\right)$.

From the above conditions, the appropriate relative coefficient of the significance of satisfying the user's request for the $j$-th type of resource $\left(\beta_{i j}\right)$, whose value is:

$$
\beta_{i j}=\frac{B_{i j}}{\mu_{i j} \cdot \sum_{j=1}^{n} \sum_{i=1}^{m}\left(B_{i j} / \mu_{i j}\right)}
$$

where: 
$B_{i j}$ - the size of the required $j$-th type of resources by the $i$-th user for the observed planning period,

$\mu_{i j}$ - the coefficient of the significance of the request of the $i$-th user for the $j$-th type of resource, and

$m$ - number of users.

In that case, the reduced amount of the $j$-th resource to the $i$-th user can be determined by the following relation:

$$
\delta_{i j}=\beta_{i j} \cdot \sum_{j=1}^{n} \Delta R_{j}
$$

In this situation, the amount of the $j$-th resource allocated to the $i$-th user is:

$$
b_{i j}^{*}=B_{i j}-\delta_{i j}
$$

The assessment of meeting the requirements of the $i$-th user with the $j$-th type of resources after reducing the planned amount is determined by the coefficient of individual service of the user:

$$
\lambda_{i j}=\frac{b_{i j}^{*}}{B_{i j}}
$$

In this way, it is ensured that the coefficient of individual customer service $\lambda_{i j}$ is equal to the coefficient of the average service $\bar{\lambda}_{j}$ of all $p$ users $(0<p \leq m)$ with the same priority of satisfying the requirements with the $j$-th type of resource.

In this case, the coefficient of average customer service with the same priority resource is:

$$
\bar{\lambda}_{j}=\frac{\sum_{i=1}^{p} b_{i j}^{*}}{\sum_{i=1}^{p} B_{i j}}
$$

The procedure in this model of allocation of limited resources ensures that the Plan of allocation of limited (insufficient) resources is rational, fair, and correct for all users because all the set conditions are met. 


\section{Requirements prioritization techniques}

One of the key problems of optimal allocation of limited resources is setting priorities to meet user needs. However, this problem can be overcome by using specific techniques, methods, and approaches of prioritization.

Numerous user prioritization techniques have been presented in the literature, see (Vestola, 2010; Achimugu et al, 2014; Khan et al, 2015; Qaddoura et al, 2017; Hudaib et al, 2018; Olaronke et al, 2018).

In general, request prioritization techniques can be divided in two categories. Techniques include requirement prioritization methods and requirements negotiation approaches (Olaronke et al, 2018).

Request prioritization methods are classified into methods that use a nominal scale, ordinal scale, and ratio scale, while approaches to negotiating claims focus on assigning priority to meeting requirements through consensus of stakeholders.

Nominal scale methods allow requests to be assigned to different priority groups, where all requests in one priority group are treated equally. Ordinal scale methods result in an orderly list, so it is possible to see which requirements are more important than the others, but not by how much, while relationship scale methods give a relative difference between requirements, i.e. they can quantify how much more important one request is than another. In addition to these methods, other methods are cited in the literature, such as Interval Scale, Hybridized Scale, and Machine Learning (Olaronke et al, 2018).

Each of these methods and techniques is characterized by different challenges, as none can be considered the best given the problems that accompany them, such as reliability, consistency, consensus when multiple stakeholders are involved, as well as difficulties when there is a large number of requirements, etc. In addition, some take more time but give more accurate results (Zou et al, 2019).

In practice, it becomes challenging for decision-makers to choose the correct method and technique when prioritizing requirements. In many cases, decision-makers are faced with the fact that not all requirements can be fully met due to limited resources and time. This means that it must be decided which of the requirements can be removed from the observed set of requirements and which requirements can be partially satisfied.

However, the development of models based on hybrid approaches that include a combination of different methods and techniques, as well as reaching consensus among stakeholders, can be considered as 
promising models in decision-making when prioritizing customer satisfaction (Wei et al, 2021).

The Requirements triage method is a handy tool for establishing relative priorities in the assessment of resources to meet user requirements, where requests are most often classified into three groups on a nominal scale, as follows:

- High priority requirements (critical, fundamental), which must be fully met;

- Standard priority requirements (quite important), which can be partially met; and

- Low priority requirements (irrelevant, not mandatory), which do not have to be met in the observed period.

After the triage of requests, the next step is to rank those requests that can be partially met according to the degree of importance depending on their position on the ranking list.

Let $X=\left\{x_{1}, x_{2}, \ldots, x_{n}\right\}$ be a set of predefined options (requirements), where $x_{i}$ represents the $i$-th requirements $(i=1, \ldots, n)$. Let $D=\left\{d_{1}, d_{2}, \ldots, d_{k}\right\}$ be a set of decision-makers, where $d_{k}$ denotes the $k$ th decision-maker $(k=1, \ldots, m)$. Each decision-maker $d_{k} \in D$ can express their preference information using different preference structures.

The procedure of the rank selection process is given as follows:

Step 1: Obtaining the individual preference vectors

Let $R_{k}=\left\{r_{1}^{k}, r_{2}^{k}, \ldots, r_{n}^{k}\right\}$ the individual ranking vector, where $r_{i}^{k}$ represents the $i$-th rank of requirements $(i=1, \ldots, n)$, which is given by the decision-maker $d_{k}$.

Step 2: Obtaining the collective preference vectors

After obtaining individual preference vectors by different decisionmakers, for calculating the collective preference vector $R_{c}=\left\{r_{1}^{c}, r_{2}^{c}, \ldots, r_{n}^{c}\right\}$, where $r_{i}$ represents the $i$-th rank of requirements $(i=1, \ldots, n)$, in this paper, the heuristic algorithm of the median Kemenia is applied (Milićević \& Milenkov, 2014). 
Step 3: Consensus reaching process

A consensus-reaching process is a dynamic and iterative groupdiscussion process that helps the decision-makers to bring their opinions closer before making a decision (Pérez, 2018 ). This process consists of several rounds where the decision-makers discuss and change their preferences according to the suggestions given by a moderator. Usually, the moderator is a person who does not participate in the discussion, but he or she helps the decision-makers to make their preferences closer to each other. The moderator's tasks are 1) computing the consensus measures, 2) checking the level of agreement, and 3) generating some advice for those decision-makers that should change their minds.

To calculate the level of consensus, the ordinal consensus degree (OCD) measures is applied in this paper, The OCD is defined as the deviation between individual preference vectors and collective preference vectors (Dong \& Zhang, 2014), as follows:

$$
O C D\left(d_{k}\right)=\frac{1}{n^{2}} \sum_{i=1}^{n}\left|r_{i}^{k}-r_{i}^{c}\right|
$$

The ordinal consensus degree among all decision-makers is given as follows:

$$
O C D\left\{d_{1}, d_{2}, \ldots, d_{m}\right\}=\frac{1}{m} \sum_{k=1}^{m} O C D\left(d_{k}\right)
$$

If the $O C D\left(d_{1}, d_{2}, \ldots, d_{m}\right)=0$, then all decision-makers have complete ordinal consensus with the collective option. Otherwise, the smaller $O C D\left\{d_{1}, d_{2}, \ldots, d_{m}\right\}$ value indicates the higher ordinal consensus level among $\left\{d_{1}, d_{2}, \ldots, d_{m}\right\}$.

When the level of consensus is not met, a feedback adjustment procedure is applied to improve the level of consensus among decisionmakers, which is repeated until a predetermined level of consensus is reached $\alpha$ (Tang et al, 2021).

\section{Methods of converting ranks into weighting coefficients}

Ranking user requirements and then converting ranks into weights has certain advantages. The main advantage of this method of determining the significance of user requests is that it is much easier to rank user requests by applying specific methods of prioritization, and then based on the obtained unified list of $n$ prioritized (ranked) requirements, determine the weighting coefficients of the significance of 
the requirements by applying specific methods for converting ranks into weight values (Tufail et al, 2019).

In the literature (Milićević \& Milenkov, 2014; Alfares \& Duffuaa, 2016), several methods for determining the weight values of the coefficients based on their rank are presented. The following methods were used in this paper:

1) Variable-slope linear (VSL) weights:

$$
w_{r}=100-\left(3.19514+\frac{37.75756}{n}\right) \cdot(r-1)
$$

2) Rank-sum (RS) weights:

$$
w_{r}=100 \cdot(n+1-r) / n
$$

3) Rank reciprocal $(R R)$ weights:

$$
w_{r}=100 / r
$$

4) Rank order centroid (ROC) weights:

$$
w_{r}=\frac{100 \cdot \sum_{i=r}^{n} 1 / i}{\sum_{i=1}^{n} 1 / i}
$$

5) Geometric weights (GW):

$$
w_{r}=\frac{100}{(\sqrt{2})^{r-1}}
$$

where:

$w_{r}$ - weight value of the coefficient of significance of the request, $r$ - rank required, $n$ - the total number of user requests.

The weight values of the coefficient of the significance of the requirements obtained by these methods are in the range from 0 to 100 . By additive normalization, these values are reduced to the interval 0-1.

In this paper, the aggregation of the weight values of the coefficient is performed by arithmetic averaging of the obtained values using the above methods, with the following expression:

$$
W_{j}=\frac{\sum_{i=1}^{q} w_{i j}}{q}
$$

where:

$q$ - the number of methods applied, and

$j=1,2, \ldots, n-$ the user request number. 


\section{Application of the resource allocation model}

For the observed planning period, the requirements of 5 users who use the same resource of the logistics system were analyzed.

The logistics support planning process was implemented through the following steps shown in Figure 2:

Step 1: Determine user requirements for a particular type of resource

After the analysis, the user requirements were grouped into ten homogeneous groups, with the total required capacity $B_{j}=7000$ of resource units, as shown in Table 1.

Table 1 - Overview of the user requests for the same type of resource Таблица 1 - Обзор запросов пользователей по одинаковому типу ресурса Табела 1 - Преглед захтева корисника за исту врсту ресурса

\begin{tabular}{l|l|l|l|l|l|l|l|l|l|l|l} 
& B1 & B2 & B3 & B4 & B5 & B6 & B7 & B8 & B9 & B10 & Total \\
\hline K1 & 300 & 200 & 0 & 100 & 100 & 100 & 250 & 100 & 150 & 200 & $\mathbf{1 5 0 0}$ \\
\hline K2 & 100 & 200 & 100 & 200 & 300 & 150 & 150 & 100 & 200 & 200 & $\mathbf{1 7 0 0}$ \\
\hline K3 & 0 & 0 & 200 & 100 & 150 & 300 & 200 & 50 & 100 & 0 & $\mathbf{1 1 0 0}$ \\
\hline K4 & 200 & 0 & 0 & 300 & 300 & 50 & 100 & 100 & 250 & 200 & $\mathbf{1 5 0 0}$ \\
\hline K5 & 0 & 100 & 200 & 50 & 150 & 0 & 300 & 150 & 100 & 150 & $\mathbf{1 2 0 0}$ \\
\hline Total & $\mathbf{6 0 0}$ & $\mathbf{5 0 0}$ & $\mathbf{5 0 0}$ & $\mathbf{7 5 0}$ & $\mathbf{1 0 0 0}$ & $\mathbf{6 0 0}$ & $\mathbf{1 0 0 0}$ & $\mathbf{5 0 0}$ & $\mathbf{8 0 0}$ & $\mathbf{7 5 0}$ & $\mathbf{7 0 0 0}$
\end{tabular}

Step 2: Determining the available capacities of the logistics system for the required type of resources

For the observed planning period, it was determined that the logistics system for the required type of resources has a capacity of $R_{j}=5000$ units of measure.

Step 3: Determining the deviation of the required (required) from the available resource capacity

Given that the total required resource capacity of the user is $B_{j}=7000$ units of measure and that the logistics system has the resource capacity of $R_{j}=5000$ units of measure, there is a shortage of resources in the system of $\Delta R_{j}=B_{j}-R_{j}=7000-5000=2000$ units of measure. 
Step 4: Select a customer satisfaction policy.

The choice of customer satisfaction policy plays a key role, given the present deficit of resource capacity of the logistics system. In this regard, the "Priority of Requirements" rule has proven in practice to be a very effective policy for the allocation of limited resources.

In this paper, the technique of request triage was first applied, where after the analysis, it was decided which requirements will be fully satisfied, which partially, and which will not be served. After that, the technique of ranking the partially met requirements was applied to determine their degree of significance to achieve the greatest global usefulness of the system.

Step 4.1: Application of the triage requirement technique

By applying the request triage technique, the decision-makers decided that the requests of users $B 7, B 8$, and $B 9$ were fully met, and the request of $B 10$ was not met. It was also decided that other requirements would be partially met by all users.

Table 2 - Overview of the user requirements after the triage Таблица 2 - Обзор запросов пользователей после сортировки Табела 2 - Преглед захтева корисника након тријаже

\begin{tabular}{l|l|l|l|l|l|l|l} 
& B1 & B2 & B3 & B4 & B5 & B6 & Total \\
\hline K1 & 300 & 200 & 0 & 100 & 100 & 100 & $\mathbf{8 0 0}$ \\
\hline K2 & 100 & 200 & 100 & 200 & 300 & 150 & $\mathbf{1 0 5 0}$ \\
\hline K3 & 0 & 0 & 200 & 100 & 150 & 300 & $\mathbf{7 5 0}$ \\
\hline K4 & 200 & 0 & 0 & 300 & 300 & 50 & $\mathbf{8 5 0}$ \\
\hline K5 & 0 & 100 & 200 & 50 & 150 & 0 & $\mathbf{5 0 0}$ \\
\hline Total & $\mathbf{6 0 0}$ & $\mathbf{5 0 0}$ & $\mathbf{5 0 0}$ & $\mathbf{7 5 0}$ & $\mathbf{1 0 0 0}$ & $\mathbf{6 0 0}$ & $\mathbf{3 9 5 0}$
\end{tabular}

Following the request triage procedure, the total required resource capacity of the users is $B_{j}=3950$ units of measure, and the available resource capacity of the logistics system is now $R_{j}=2700$ units of measure. So, there is still a deficit of resources in the system, which now amounts to:

$$
\Delta R_{j}=B_{j}-R_{j}=3950-2700=1250
$$


Step 4.2: Ranking the requests that are partially served

In the process of determining the degree of significance of the requests that are partially served, five decision-makers participated in ranking the requests $\mathrm{B} 1, \mathrm{~B} 2, \mathrm{~B} 3, \mathrm{~B} 4, \mathrm{~B} 5$, and $\mathrm{B} 6$.

Table 3 provides an overview of the ranked user requirements by the decision-makers.

Table 3- Overview of the ranked user requests by the decision makers Таблица 3 - Проверка ранжированных запросов пользователей ответственным лицом, принимающим решения

Табела 3 - Преглед рангираних захтева корисника од стране доносиоца одлуке

\begin{tabular}{c|c|c|c|c|c|c|}
$\begin{array}{c}\text { Decision- } \\
\text { makers }\end{array}$ & B1 & B2 & B3 & B4 & B5 & B6 \\
\hline DM1 & 1 & 2 & 4 & 3 & 6 & 5 \\
\hline DM2 & 1 & 2 & 3 & 4 & 6 & 5 \\
\hline DM3 & 3 & 1 & 2 & 5 & 4 & 6 \\
\hline DM4 & 1 & 2 & 3 & 4 & 5 & 6 \\
\hline DM5 & 2 & 1 & 3 & 5 & 4 & 6
\end{tabular}

Step 4.3: Consolidate individually ranked requests into a group rank

Consolidation of individually ranked requests by a group of decisionmakers into the final group order was done by applying the heuristic algorithm to determine the Kemeny median.

After performing the procedure of binary relations between ranking pairs, the obtained elements of the loss matrix are shown in Table 4.

Table 4 - Loss matrix element values

Таблица 4 - Значения элементов матрицы потерь

Табела 4 - Вредности елемената матрице губитака

\begin{tabular}{l|l|l|l|l|l|l} 
& B1 & B2 & B3 & B4 & B5 & B6 \\
\hline B1 & 0 & 6 & 2 & 0 & 0 & 0 \\
\hline B2 & 4 & 0 & 0 & 0 & 0 & 0 \\
\hline B3 & 8 & 10 & 0 & 2 & 0 & 0 \\
\hline B4 & 10 & 10 & 8 & 0 & 4 & 0 \\
\hline B5 & 10 & 10 & 10 & 6 & 0 & 4 \\
\hline B6 & 10 & 10 & 10 & 10 & 6 & 0
\end{tabular}


Table 5 shows the procedure for applying the Kemeny median algorithm to obtain the final group order of user requests in accordance with the degree of significance.

Table 5 - Application of the heuristic algorithm of the Kemeny median to obtain a group order

Таблица 5 - Применение эвристического алгоритма медианы Кемени для получения группового порядка

Табела 5 - Примена хеуристичког алгоритма медијане Кеменија за добијање групног поретка

\begin{tabular}{l|l|l|l|l|l|l} 
& $s_{i}^{(1)}$ & $s_{i}^{(2)}$ & $s_{i}^{(3)}$ & $s_{i}^{(4)}$ & $s_{i}^{(5)}$ & $s_{i}^{(6)}$ \\
\hline B1 & 8 & $\mathbf{2}$ & & & & \\
\hline B2 & $\mathbf{4}$ & & & & & \\
\hline B3 & 30 & 10 & $\mathbf{2}$ & & & \\
\hline B4 & 34 & 22 & 12 & $\mathbf{4}$ & & \\
\hline B5 & 42 & 30 & 20 & 10 & $\mathbf{4}$ & \\
\hline B6 & 26 & 36 & 26 & 16 & 6 & $\mathbf{0}$
\end{tabular}

The final group rank of the requests is $\mathrm{B} 2, \mathrm{~B} 1, \mathrm{~B} 3, \mathrm{~B} 4, \mathrm{~B} 5$, and $\mathrm{B} 6$.

Step 4.4: To calculate consensus levels

By applying Eqs. (12) and Eqs. (13), the level of consensus is calculated, which is $O C D=0.08889$. The obtained level of consensus is satisfactory, which means that the decision-makers do not need to adjust their preferences.

Step 4.5: Determining the weight values of the coefficient of the significance of the requirements

Table 6 shows the weight values of the coefficients of the significance of the requirements based on their rank, obtained by applying the method of converting the ranks into weight values. 
Table 6 - Weight values of the coefficient of significance of the request Таблица 6- Весовые значения коэффрициента значимости запроса Табела 6 - Тежинске вредности коефицијената значајности захтева

\begin{tabular}{c|c|c|c|c|c|c} 
& B2 & B1 & B3 & B4 & B5 & B6 \\
\hline VLS & 0.2185 & 0.1978 & 0.1770 & 0.1563 & 0.1356 & 0.1148 \\
\hline RS & 0.2857 & 0.2381 & 0.1905 & 0.1429 & 0.0952 & 0.0476 \\
\hline RR & 0.4082 & 0.2041 & 0.1361 & 0.1020 & 0.0816 & 0.0680 \\
\hline ROC & 0.4083 & 0.2417 & 0.1583 & 0.1028 & 0.0611 & 0.0278 \\
\hline GW & 0.3347 & 0.2367 & 0.1674 & 0.1183 & 0.0837 & 0.0592 \\
\hline Wj & $\mathbf{0 . 2 7 6 3}$ & $\mathbf{0 . 2 1 8 1}$ & $\mathbf{0 . 1 7 1 4}$ & $\mathbf{0 . 1 3 7 5}$ & $\mathbf{0 . 1 1 0 1}$ & $\mathbf{0 . 0 8 6 6}$
\end{tabular}

Step 5: Development of alternative planning solutions

By applying the model, alternative solutions for selecting the optimal Logistic Support Plan have been developed, depending on the weight values of the coefficients of the significance of the requirements $\mu_{j}$, which are shown in Table 7.

From Table 7, it can be seen that the difference between the maximum and minimum values of the percentage of customer service in the VLS method is 18.80, in the RS method 55.08, In the RR method 41.26, in the ROC method 69.33, while in the GW method it is 46.26.

The difference between the maximum and minimum values of the percentage of customer service in the arithmetically combined group value of weight coefficients $W_{j}$ is 33.08 .

Step 6: Selection of the planning solution

After analysing acceptable planning solutions for developing the optimal Logistic Support Plan, the resource allocation was selected based on the values of weighting coefficients $W_{j}$.

Step 7: Detailed elaboration of the selected planning solution

In this step, a customer service order with the allocated amount of resources in the observed planning period is elaborated. 


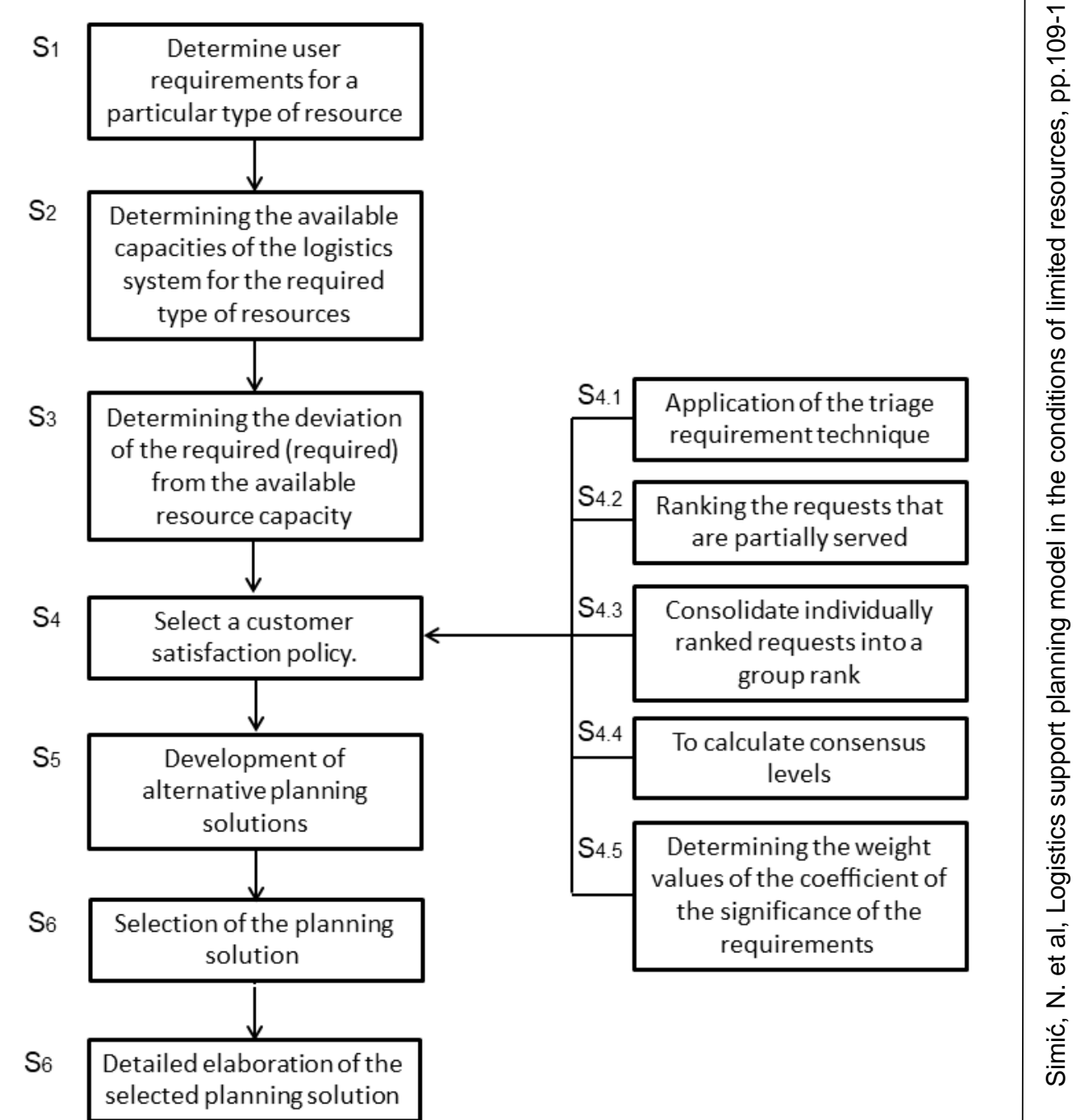

Figure 2 - Flowchart of the proposed methodology

Puc. 2 - Блок-схема предлагаемой методологии

Слика 2 - Дијаграм тока предложене методологије 


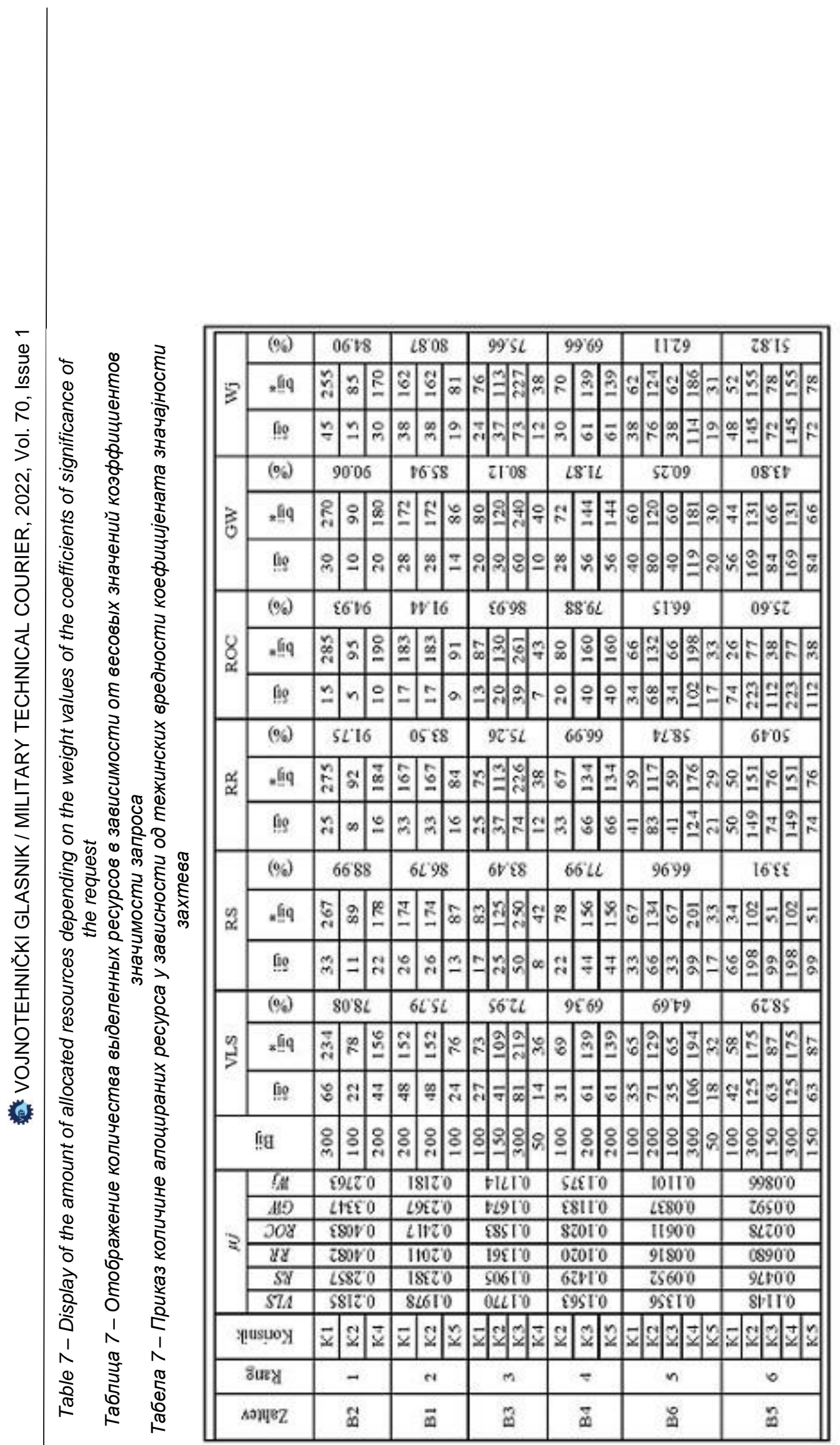




\section{Conclusion}

In logistics systems, there is often a need to make decisions regarding the allocation of limited resources. Resource allocation efficiency is measured by optimizing appropriate parameters such as demand size, resource capacity, task execution time, system latency, and cost, which are key elements in planning the logistics support of military operations.

The considerable uncertainty and dynamics of the requirements generated by military units (users of logistic products and services), and, on the other hand, numerous limitations present in logistics indicate that logistics support planning is a crucial and challenging area of logistics.

Optimal planning reduces or eliminates the uncertainty of future activities and maintains the system within the permissible (tolerant) framework of functionality in the observed future period.

To plan logistics support well, it is necessary to have reliable data on customer requirements, as well as data on the availability of limited resources of the logistics system. In addition, quality planning implies applying modern methods, techniques, and software tools, which will provide greater rationality and objectivity in determining the variants of planning solutions.

This paper has shown that techniques for prioritizing customer requirements and resource allocation provide a possibility of agile planning of logistics support and ensure optimal allocation of limited resource capacities of the logistic system. The goal in future research is to consider the possibility of applying the allocation of multiple resources, in multiperiod, according to priorities, and by substitution of resources to finally obtain, as much as it is possible, an automated logistics support plan ready to respond to all possible scenarios.

Due to the extraordinary dynamism and heterogeneity of phenomena in logistics activities, logistics support planning cannot be fully and easily formalized and automated. In that sense, the efficiency of logistics support planning depends on creativity, organizational skills, and innovation in the work of logistics staff.

\section{References}

Achimugu, P., Selamat, A., Ibrahim, R. \& Mahrin, M.N. 2014. A systematic literature review of software requirements prioritization research. Information and Software Technology, 56(6), pp.568-585. Available at: https://doi.org/10.1016/j.infsof.2014.02.001. 
Alfares, H.K. \& Duffuaa, S.O. 2016. Simulation-based evaluation of criteria rank-weighting methods in multi-criteria decision-making. International Journal of Information Technology \& Decision Making, 15(01), pp.43-61. Available at: https://doi.org/10.1142/S0219622015500315.

Andrejić, M. 2001. Methods and software for the support of planning in logistic organizational systems. Vojnotehnički glasnik /Military Technical Courier, 49(1), pp.36-52 (in Serbian). Available at: https://doi.org/10.5937/vojtehg0101036A.

Andrejić, M., Nikolić, N. \& Stojković, D. 2004. Logistička podrška logističkim operacijama. Vojnotehnički glasnik /Military Technical Courier, 52(3-4), pp.275285 (in Serbian). Available at: https://doi.org/10.5937/vojtehg0404275A.

Chevaleyre, Y., Dunne, P., Endriss, U., Lang, J., Lemaitre, M., Maudet, N., Padget, J., Phelps, S., Rodrıguez-Aguilar, J. \& Sousa, P. 2006. Issues in multiagent resource allocation. Informatica, 30(1), pp.3-31 [online]. Available at: https://www.informatica.si/index.php/informatica/article/view/70 [Accessed: 5 July 2021].

Daoud, A., Balbo, F., Gianessi, P. \& Picard, G. 2021. A Generic MultiAgent Model for Resource Allocation Strategies in Online On-Demand Transport with Autonomous Vehicles. In: Proceedings of the 20th International Conference AAMAS 2021, London, UK, p.3, May, hal-03093017 [online]. Available at: https://tel.archives-ouvertes.fr/DEMO-ENSMSE/hal-03093017v1 [Accessed: 5 July 2021].

Dong, Y. \& Zhang, H. 2014. Multiperson decision making with different preference representation structures: A direct consensus framework and its properties. Knowledge-Based Systems, 58, pp.45-57. Available at: https://doi.org/10.1016/j.knosys.2013.09.021.

Hameed, A., Khoshkbarforoushha, A., Ranjan, R., Jayaraman, P.P., Kolodziej, J., Balaji, P., Zeadally, S, Malluhi, Q.M., Tziritas, N., Vishnu, A., Khan, S.U. \& Zomaya, A. 2016. A survey and taxonomy on energy-efficient resource allocation techniques for cloud computing systems. Computing, 98(7), pp.751774. Available at: https://doi.org/10.1007/s00607-014-0407-8.

Hudaib, A., Masadeh, R., Qasem, M. \& Alzaqebah, A. 2018. Requirements prioritization techniques comparison. Modern Applied Science, 12(2), pp.62-80. Available at: https://doi.org/10.5539/mas.v12n2p62.

Hurley, P.C.Jr \& Coleman, H.H. 2018. What FM 3-0 means for expeditionary battlefield sustainment. Army Sustainment, May-June [online]. Available at: https://www.army.mil/article/203894 [Accessed: 5 July 2021].

Jia, Q., Wang, T-n \& Zhang, Y-c. 2020. A New Mode of Army Equipment Support. Journal of Physics: Conference Series, 1649, pp.1-8. Available at: https://doi.org/10.1088/1742-6596/1649/1/012042.

Khan, J.A., Rehman, I.U., Khan, Y.H., Khan, I.J. \& Rashid, S. 2015. Comparison of Requirement Prioritization Techniques to Find Best Prioritization Technique. International Journal of Modern Education \& Computer Science, 7(11), pp.53-59. Available at: https://doi.org/10.5815/ijmecs.2015.11.06. 
Kostiuchenko, L. \& Solomon, D. 2020. The basic terminology of the modern military logistics. Intellectualization of logistics and supply chain management, 1(1), pp.91-98. Available at: https://doi.org/10.46783/smart-scm/2020-1-8.

Lehtola, L., Kauppinen, M. \& Kujala, S. 2004. Requirements Prioritization Challenges in Practice. In: Bomarius, F. \& lida, H. (Eds.) Product Focused Software Process Improvement. PROFES 2004. Lecture Notes in Computer Science, 3009, pp.497-508. Springer, Berlin, Heidelberg. Available at: https://doi.org/10.1007/978-3-540-24659-6_36. ISBN: 978-3-540-24659-6.

$\mathrm{Li}$, X., Li, A. \& Guo, X. 2020. The sustainable development-oriented development and utilization of renewable energy industry - A comprehensive analysis of MCDM methods. Energy, 212(art.number:118694). Available at: https://doi.org/10.1016/j.energy.2020.118694.

Luss, H. 1999. On Equitable Resource Allocation Problems: A Lexicographic Minimax Approach. Operations Research 47(3), pp.361-378, Available at: https://doi.org/10.1287/opre.47.3.361.

Luss, H. 2012. Equitable resource allocation: Models, Algorithms, and Applications. Hoboken, NJ: John Wiley \& Sons. ISBN: 978-1-118-05468-0.

McConnell, B.M., Hodgson, T.J., Kay, M.G., King, R.E., Liu, Y., Parlier, G.H., Thoney-Barletta, K. \& Wilson, J.R. 2021. Assessing uncertainty and risk in an expeditionary military logistics network. Journal of Defense Modeling and Simulation: Applications, Methodology, Technology, 18(2), pp.135-156. Available at: https://doi.org/10.1177/1548512919860595.

McConnell, B.M. \& King, R. 2019. Expeditionary Logistics Analysis for Decision Support. Technical Report. North Carolina State University Raleigh United States [online]. Available at: https://apps.dtic.mil/sti/citations/AD1092064 [Accessed: 5 July 2021].

Meran, G., Siehlow, M. \& von Hirschhausen, C. 2021. Integrated Water Resource Management: Principles and Applications. In: The Economics of Water, pp.23-121. Springer, Cham. Available at: https://doi.org/10.1007/978-3030-48485-9_3. ISBN: 978-3-030-48485-9.

Milenkov, M.A., Sokolović, V.S., Milovanović, V.R. \& Milić, M.D. 2020. Logistics: Its role, significance and approaches. Vojnotehnički glasnik/Military Technical Courier, 68(1), pp.79-106. Available at: https://doi.org/10.5937/vojtehg68-24805.

Milićević, M.R., \& Milenkov, M.A. 2014. Determination of criteria weights using ranking. Vojnotehnički glasnik/Military Technical Courier, 62(1), pp.141166 (in Serbian). Available at: https://doi.org/10.5937/vojtehg62-3878.

Moisiadis, F. 2002. The fundamentals of prioritizing requirements. In: Proceedings of the systems engineering, test and evaluation conference (SETE'2002), Sydney, Australia, October [online]. Available at: https://citeseerx.ist.psu.edu/viewdoc/download?doi=10.1.1.92.4036\&rep=rep1\&t ype=pdf [Accessed: 6 July 2021].

Ogryczak, W., Luss, H., Pióro, M., Nace, D. \& Tomaszewski, A. 2014. Fair optimization and networks: A survey. Journal of Applied Mathematics, art.ID:612018. Available at: https://doi.org/10.1155/2014/612018. 
Olaronke, I., Rhoda, I. \& Ishaya, G. 2018. An appraisal of software requirement prioritization techniques. Asian Journal of Research in Computer Science, $1(1)$ pp.1-16. Available

at: https://doi.org/10.9734/ajrcos/2018/v1i124717.

Pamučar, D.S. \& Savin, L.M. 2020. Multiple-criteria model for optimal offroad vehicle selection for passenger transportation: BWM-COPRAS model. Vojnotehnički glasnik/Military Technical Courier, 68(1), pp.28-64. Available at: https://doi.org/10.5937/vojtehg68-22916.

Pérez, I.J., Cabrerizo, F.J., Alonso, S., Dong, Y.C., Chiclana, F. \& HerreraViedma, E. 2018. On dynamic consensus processes in group decision making problems. Information Sciences, 459, pp.20-35. Available at: https://doi.org/10.1016/j.ins.2018.05.017.

Qaddoura, R., Abu-Srhan, A., Qasem, M.H. \& Hudaib, A. 2017. Requirements prioritization techniques review and analysis. In: 2017 International Conference on New Trends in Computing Sciences (ICTCS), Amman, Jordan, pp.258-263, October 11-13. Available at: https://doi.org/10.1109/ICTCS.2017.55.

Rogers, M.B., McConnell, B.M., Hodgson, T.J., Kay, M.G., King, R.E., Parlier, G. \& Thoney-Barletta, K. 2018. A Military Logistics Network Planning System. Military Operations Research, 23(4), pp.5-24 [online]. Available at: https://www.jstor.org/stable/26553094 [Accessed: 5 July 2021].

Sarma, D., Das, A., Dutta, P. \& Bera, U.K. 2020. A Cost Minimization Resource Allocation Model for Disaster Relief Operations With an Information Crowdsourcing-Based MCDM Approach. IEEE Transactions on Engineering Management, pp.1-21., Available at: https://doi.org/10.1109/TEM.2020.3015775.

Schwartz, B., McConnell, B.M. \& Parlier, G.H. 2019. How Data Analytics Will Improve Logistics Planning. Army Sustainment, 51(3), pp.54-57 [online]. Available at: https://alu.army.mil/alog/ARCHIVE/PB700201903FULL.pdf [Accessed: 5 July 2021].

Skobelev, P. 2011. Multi-agent systems for real-time resource allocation, scheduling, optimization and controlling: industrial applications. In: Mařík, V., Vrba, P., Leitão, P. (Eds.) Holonic and Multi-Agent Systems for Manufacturing. HoloMAS 2011. Lecture Notes in Computer Science, 6867, pp.1-14. Berlin, Heidelberg: Springer. Available at: https://doi.org/10.1007/978-3-642-23181-0_1. ISBN: 978-3-642-23181-0.

Tang, H., Wan, S., Li, C-C., Liang, H. \& Dong, Y. 2021. Consensus Reaching Process in the Two-Rank Group Decision-Making with Heterogeneous Preference Information. International Journal of Computational Intelligence Systems, 14(1), pp.758-768. Available at: https://doi.org/10.2991/ijcis.d.210201.001.

Tufail, H., Qasim, I., Masood, M.F., Tanvir, S. \& Butt, W.H. 2019. Towards the selection of Optimum Requirements Prioritization Technique: A Comparative Analysis. In: The 5th International Conference on Information Management, Cambridge, UK, pp.227-231, March 24-27. Available at: https://doi.org/10.1109/INFOMAN.2019.8714709. 
Vestola, M. 2010. A comparison of nine basic techniques for requirements prioritization, pp.1-8. Helsinki University of Technology [online]. Available at: http://www.mvnet.fi/publications/software_development_seminar.pdf [Accessed: 5 July 2021].

Wei, X., Quan, S., , Shi zhuang, Y, Yan song, A. \& Gang, Q. 2021. Research on Dynamic Resource Allocation and Decision-making Model of Equipment Independent Maintenance. Journal of Physics: Conference Series, 1939, pp.1-9. Available at: https://doi.org/10.1088/1742-6596/1939/1/012014.

Zeimpekis, V., Kaimakamis, G. \& Daras, N.J. 2015. Military logistics: research advances and future trends. Springer. Available at: https://doi.org/10.1007/978-3-319-12075-1. ISBN: 978-3-319-12075-1.

Zlatnik, D. \& Mares, J. 2020. Ammunition supplies, new proposal of ammunition sufficiency. Vojnotehnički glasnik/Military Technical Courier, 68(2), pp.250-267. Available at: https://doi.org/10.5937/vojtehg68-25193.

Zou, H., Liu, D., Guo, S., Xiong, L., Liu, P., Yin, J., Zeng, Y., Zhang, J. \& Shen, Y. 2019. Quantitative assessment of adaptive measures on optimal water resources allocation by using reliability, resilience, vulnerability indicators. Stochastic Environmental Research and Risk Assessment, 34, pp.103-199. Available at: https://doi.org/10.1007/s00477-019-01753-4.

МОДЕЛЬ ПЛАНИРОВАНИЯ ЛОГИСТИЧЕСКОЙ ПОДДЕРЖКИ В УСЛОВИЯХ ОГРАНИЧЕННЫХ РЕСУРСОВ

Никола Б. Симич ${ }^{a}$, Марьян А. Миленков ${ }^{\mathrm{a}}$,

Владимир Р. Миловановича , Влада С. Соколовича , корреспондент,

Павел Й. Фольтин ${ }^{6}$, Балаж Й. Такшас ${ }^{8}$

а Университет обороны в г. Белград, Военная академия,

Департамент логистики, г. Белград, Республика Сербия

б Университет обороны в Брно, факультет военного руководства, Департамент материально-технического обеспечения, г. Брно, Чешская Республика

в Университет государственной службы, фракультет военных наук и подготовки офицеров, фракультет снабжения, фринансов и военного транспорта, г. Будапешт, Венгрия

РУБРИКА ГРНТИ: 81.00.00 ОБЩИЕ И КОМПЛЕКСНЫЕ ПРОБЛЕМЫ ТЕХНИЧЕСКИХ И ПРИКЛАДНЫХ НАУК И ОТРАСЛЕЙ НАРОДНОГО ХОЗЯЙСТВА:

81.88.00 Материально-техническое снабжение. Логистика;

81.88.75 Экономика, организация, управление, планирование и прогнозирование в

ВИД СТАТЬИ: оригинальная научная статья материальнотехническом снабжении 
Резюме:

Введение: В статье представлена модель планирования логистической поддержки в условиях ограниченных логистических ресурсов, основанная на приоритезации запросов клиентов и распределении ресурсов. Лица, принимающие решения, играют ключевую роль в эффрективном и справедливом распределении ресурсов, поскольку они определяют приоритеты среди различных запросов пользователей.

Методы. Для определения степени важности требований пользователя были применены методы приоритизации запросов с использованием номинальной шкалы, порядковой шкалы и шкалы отношений, а также пять методов преобразования ранга в весовые коэффрициенты. Метод сортировки запросов использовался для определения относительных приоритетов, в то время как эвристический алгоритм определения медианы Кемени использовался для объединения индивидуально ранжированных запросов в групповой ране. Чтобы уравновесить противоположные требования пользователей, использовались консенсусные меры группового принятия решений. Для получения оптимального планировочного решения логистической поддержки применены методы и приемы распределения ресурсов.

Результаты: Разработана модель адаптивного планирования логистической поддержки в условиях ограниченных ресурсных возможностей логистической системы.

Вывод: Предложенная модель может быть эфрфективно применена и в других сфрерах распределения ресурсов.

Ключевые слова: планирование логистики, приоритезация запросов, сортировка, преобразование рангов, веса, распределение ресурсов.

\section{МОДЕЛ ПЛАНИРАЊА ЛОГИСТИЧКЕ ПОДРШКЕ У УСЛОВИМА} ОГРАНИЧЕНИХ РЕСУРСА

Никола Б. Симић ${ }^{\mathrm{a}}$ Марјан А. Миленков ${ }^{\mathrm{a}}$,

Владимир Р. Миловановић ${ }^{\mathrm{a}}$, Влада С. Соколовић ${ }^{\mathrm{a}}$, аутор за преписку, Павел J. Фолтин ${ }^{6}$, Балаж J. Такшас ${ }^{8}$

а Универзитет одбране у Београду, Војна академија, Катедра логистике, Београд, Република Србија

б Универзитет одбране у Брну, Факултет за војно руководство, Одсек за логистику, Брно, Чешка Република

в Универзитет за јавне службе, Факултет војних наука и обуку официра, Одсек за снабдевање, финансије и војни саобраћај,

Будимпешта, Мађарска

ОБЛАСТ: логистика, инжињерски менаџмент, информационе технологије ВРСТА ЧЛАНКА: оригинални научни рад 


\section{Сажетак:}

Увод: У раду је представљен модел планирања логистичке подршке у условима ограничених логистичких ресурса на основу приоритизације захтева купаца и алокације ресурса. Доносиоци одлука имају кључну улогу у ефикасној и правичној алокацији ресурса јер дају приоритет различитим захтевима корисника.

Методе: Технике приоритизације захтева које користе номиналну скалу, ординалну скалу и скалу односа, као и пет метода за претварање ранга у тежинске коефицијенте, примењене су како би се одредио степен значаја захтева корисника. За утврђивање релативних приоритета коришћен је метод тријаже захтева, док је хеуристички алгоритам за одређивање медијане Кеменија коришћен за консолидацију индивидуално рангираних захтева у групни ранг. Ради балансирања супротстављених захтева корисника, коришћене су мере консензуса групног одлучивања. За добијање оптималног планског решења логистичке подршке примењене су методе и технике расподеле ресурса.

Резултати: Развијен је модел за адаптивно планирање логистичке подршке у условима ограничених ресурсних капацитета логистичког система.

Закључак: Предложени модел може се ефикасно применити и у другим областима алокације ресурса.

Кључне речи: планирање логистике, приоритизација захтева, тријажа, претварање ранга у пондере, алокација ресурса.

Paper received on / Дата получения работы / Датум пријема чланка: 10.07.2021. Manuscript corrections submitted on / Дата получения исправленной версии работы / Датум достављања исправки рукописа: 03.01.2022.

Paper accepted for publishing on / Дата окончательного согласования работы / Датум коначног прихватања чланка за објављивање: 04.01.2022.

(c) 2022 The Authors. Published by Vojnotehnički glasnik / Military Technical Courier (www.vtg.mod.gov.rs, втг.мо.упр.срб). This article is an open access article distributed under the terms and conditions of the Creative Commons Attribution license (http://creativecommons.org/licenses/by/3.0/rs/).

(c) 2022 Авторы. Опубликовано в «Военно-технический вестник / Vojnotehnički glasnik / Military Technical Courier» (www.vtg.mod.gov.rs, втг.мо.упр.срб). Данная статья в открытом доступе и распространяется в соответствии с лицензией «Creative Commons» (http://creativecommons.org/licenses/by/3.0/rs/).

(c) 2022 Аутори. Објавио Војнотехнички гласник / Vojnotehnički glasnik / Military Technical Courier (www.vtg.mod.gov.rs, втг.мо.упр.срб). Ово је чланак отвореног приступа и дистрибуира се у складу са Creative Commons лиценцом (http://creativecommons.org/licenses/by/3.0/rs/).

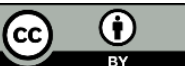

